\title{
The influence of adsorption chillers on CHP power plants
}

\author{
Karol Sztekler ${ }^{*}$, Wojciech Kalawa $^{1}$, Sebastian Stefański ${ }^{1}$, Jarosław Krzywanski $^{2}$, Karolina Grabowska ${ }^{2}$, Marcin \\ Sosnowski ${ }^{2}$, and Wojciech Nowak ${ }^{1}$ \\ ${ }^{1}$ AGH University of Science and Technology, Faculty of Energy and Fuels, 30-059 Cracow, Poland \\ ${ }^{2}$ Jan Dlugosz University in Czestochowa, Faculty of Mathematics and Natural Sciences, 42-200 Czestochowa, Poland
}

\begin{abstract}
The simultaneous production of electricity, heat and cooling, the so-called trigeneration, allows for substantial savings in the chemical energy of fuels. More efficient use of the primary energy contained in fuels translates into tangible earnings for power plants while reductions in the amounts of fuel burned, and of non-renewable resources in particular, certainly have a favourable impact on the natural environment. The main aim of the above-described project was to analyse the influence of use adsorption contacted to conventional CHP power plant. An adsorption chiller is an item of industrial equipment that is driven by low grade heat and intended to produce chilled water and desalinated water. Adsorption chillers ACH can by used for utilization heat from many industrial process where temperature medium is too low for use absorption chillers. In this article modelled the cycle of a conventional heat power plant integrated with an adsorption chiller-based plant. Multi-variant simulation calculations were performed using IPSEpro simulation software.
\end{abstract}

\section{Introduction}

Polish electricity production is mainly based on conventional fuels, particularly hard coal and lignite (jointly 79\%); sources with smaller shares in electricity production include: RES $13 \%$, gaseous fuels $5 \%$, biomass and others 3\%. In 2016, electricity power production in Poland 166.6 TWh while its consumption was 159.1 TWh. In 2016, the total thermal capacity installed at the licenced heat producers was $\quad 54,259.8 \mathrm{MW}$, and the generation capacity was $53,434.7 \mathrm{MW}$ of which heat supplied to consumers connected to the network was 235,545.9 TJ. With regard to heat production, the predominant fuel utilised for this purpose is coal $75 \%$; followed by gaseous fuels $7.2 \%$ and RES 7.6\%. Production of heat in cogeneration units used 2,230,263,334 GJ energy from coal fuels [1-3].

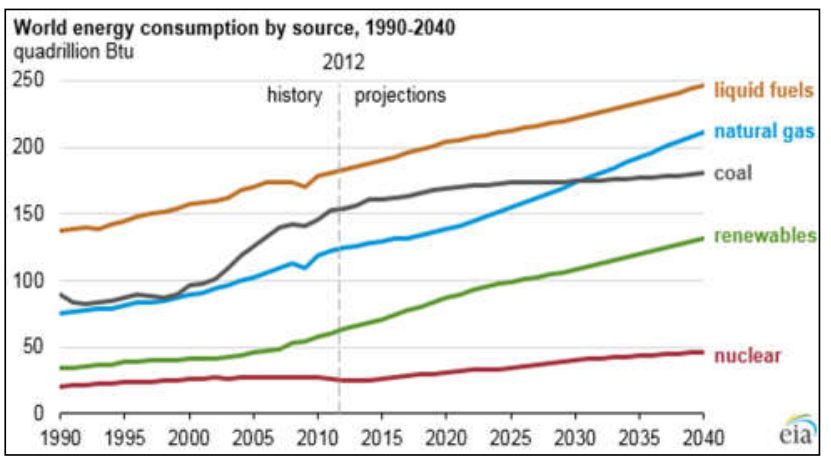

Fig. 1. World energy consumption by source [1].

According to figure number one fossil fuels still will be dominate fuels use for production energy.

\footnotetext{
* Corresponding author: sztekler@agh.edu.pl
}

The use of fossil fuels implies a lot of adverse effects on the environment, such as global warming, acid rain, smog as well as soil and water pollution. Counteracting this phenomenon involves increasing the efficiency of electricity production and searching for more efficient methods of conversion of the chemical energy of a fuel to electricity or replacing existing fuels with ones that are more environmentally friendly. One of the ways to increase the efficiency of the use of chemical energy from fuels with simultaneous reduction of the negative effect on the environment is generation through CHP (Combined Heat and Power) or through polygeneration, i.e. generation of an extra utility beside heat and electricity, e.g. cooling or compressed air. This paper presents the possibility of increasing the effectiveness of cogeneration units through the application of adsorption chillers fed by heat from the terminal unit of the district heat network. The greater quantity of heat generated from combusting fuels will be effectively utilised to, inter alia, feed chillers and the cooling produced will be used for example for air conditioning. This will contribute to a reduction in energy consumption for cooling purposes while at the same time reducing the amount of heat that remains unused in the process of generating electricity at conventional power plants, and consequently to savings in fossil fuels and improving the condition of the environment we live in [4-6]. 


\section{Modelling process}

\subsection{Adsorption chillers}

The operating principle of an adsorption cooling system (Figure 2) consists of evaporating the refrigerant in the evaporator under reduced pressure.

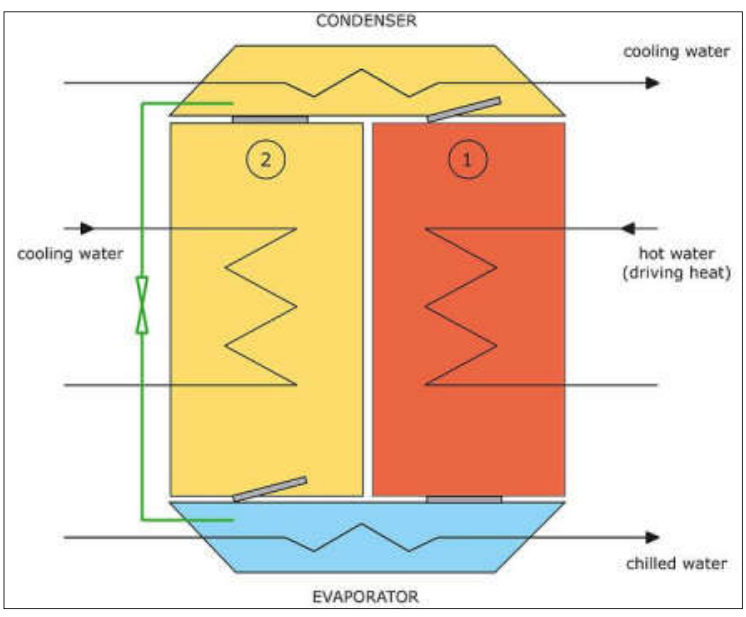

Fig. 2. Adsorption cooling-desalination system [4].

The process takes place without the use of a mechanical compressor but takes advantage of the thermal effect of adsorption and desorption. The system operates on a cyclical basis and the process of adsorption and desorption (bed regeneration) takes place alternately. Refrigerant vapours discharged from the evaporator are adsorbed in an adsorption bed, which is accompanied by the generation of heat which is absorbed by the cooling water [13]. In order to enable further operation of the bed, it is necessary to remove the adsorbate from the adsorbent (desorption). This process requires the application of heat from an external source. Refrigerant vapours released in the desorption process are discharged into the evaporator. In a closed system, the condensate from the condenser is fed back to the evaporator. It is possible to apply an adsorption chiller with an open system and using water as the refrigerant. The constant feeding of water from an external source results in producing condensate that is devoid of the substances dissolved in the feed water. Therefore, they can be used in the utilisation of waste heat in power plants and in combined heat and power plant [710]. For analysis will choose Adsorption chiller BryAir ADC Series D-FRAME F-200. The main parameters of ADC chiller present in table 1 .

Table 1. Technical specification of BryAir chiller ADC Series F-FRAME F-200 [11].

\begin{tabular}{|c|c|}
\hline Cooling capacity & $900 \mathrm{~kW}$ \\
\hline Electricity consumption & $1.3-2.4 \mathrm{~kW}$ \\
\hline Refrigerant type & Water \\
\hline $\begin{array}{c}\text { Heat for regeneration Temperature } \\
\text { range }\end{array}$ & $52^{\circ} \mathrm{C}-93^{\circ} \mathrm{C}$ \\
\hline $\begin{array}{c}\text { Temperature drop for regeneration } \\
\text { process }\end{array}$ & $\Delta t=6,6^{\circ} \mathrm{C}$ \\
\hline Chilled water & $3^{\circ} \mathrm{C}-20^{\circ} \mathrm{C}$ \\
\hline
\end{tabular}

$$
\text { Condenser water }
$$

$10^{\circ} \mathrm{C}-39^{\circ} \mathrm{C}$

The value of the regeneration capacity of a chiller working based on the silica gel/water pairing is variable and strongly dependent on the hot water inlet temperature. Based on the graph in Fig. 3.

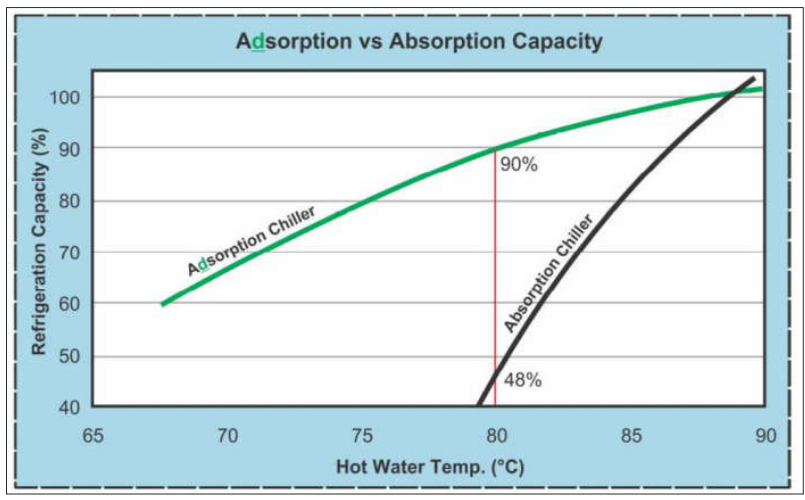

Fig. 3. Influence hot water temperature on refrigeration capacity adsorption-absorption chillers [11].

Adsorption cooling systems are being dynamically improved. Their range of application is expanding, and in combination with renewable energy sources they can make a cheap source of cooling. Commercialisation of the solutions found in adsorption cooling industry is possible if the most essential disadvantages are eliminated, i.e. the small cooling capacity in relation to the mass of the installation and the fluctuations in the cooling performance resulting from the cyclic character of operation.

\subsection{CHP power plant}

The thermodynamic cycle of a cogeneration system considered based on the example of the CHP plant in Czestochowa with a power of $64 \mathrm{MW}$ was defined numerically in the IPSEpro software based on the design parameters. The main parameters of the system have been presented in Table 2.

Table 2. Main parameters of the CHP plant [12].

\begin{tabular}{|c|c|}
\hline \multicolumn{2}{|c|}{ CHP operating parameters } \\
\hline Nominal output of superheated steam & $280 \mathrm{t} / \mathrm{h}$ \\
\hline Fresh steam temperature & $515^{\circ} \mathrm{C}$ \\
\hline Fresh steam pressure in the boiler & $111 \mathrm{Bar}$ \\
\hline Feed water temperature & $230^{\circ} \mathrm{C}$ \\
\hline Electrical power of the generator & $64 \mathrm{MWe}$ \\
\hline Heating capacity & $121,25 \mathrm{MW}$ \\
\hline Supply water temperature & $86^{\circ} \mathrm{C}$ \\
\hline Return water temperature & $57^{\circ} \mathrm{C}$ \\
\hline
\end{tabular}

Apart from generating power, a CHP plant provides end users with large amounts of heat that can also be effectively utilised for coolant production. In order to increase the energy efficiency of the power plant, a proportion of the heat generated in the cogeneration 
process will be used to generate coolant through the use of adsorption chillers for this purpose.

To maintain a high level of electricity production, the heat and power plant must also produce heat. In the summer heat it is usually not used, so you need to get an additional demand for its reception or "release" them into the atmosphere in wet or dry towers, as it happens in condensing power plants. Figure 4 shows integration adsorption chiller with CHP power plant.

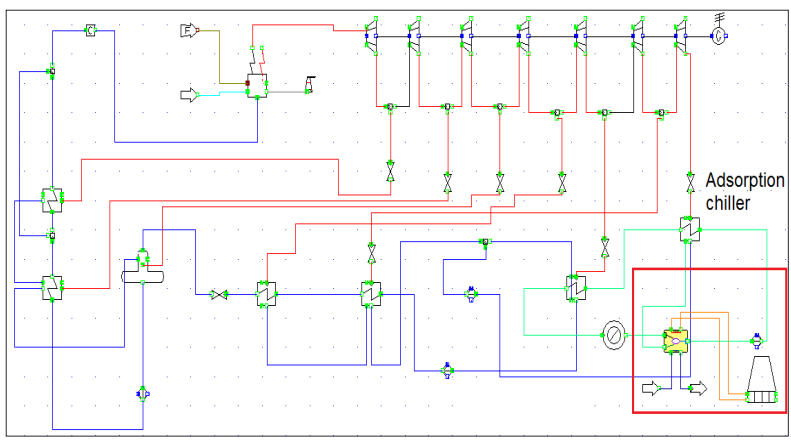

Fig. 4. CHP power plant integration with adsorption chiller.

Traditionally, during the summer, heat is used to heat utility water, but it is only 10 to $15 \%$ of the total heat output. Thus, the adsorption system increases the efficiency of the heat and power plant in the summer season, i.e. outside the heating season. Therefore, in the summer period it is possible to maintain the level of efficiency from the heating period $(85-90 \%)$ if we obtain a sufficient number of cold consumers. Table 3 shows results this analysis [11].

Table 3. Summary of the most important data

\begin{tabular}{|c|c|c|c|}
\hline Name of parameter & Symbol & Value & Unit \\
\hline $\begin{array}{c}\text { Return water from the district } \\
\text { heating network }\end{array}$ & $\mathrm{T}_{\mathrm{z}}$ & 57 & ${ }^{\circ} \mathrm{C}$ \\
\hline CHP electrical capacity & $\mathrm{N}_{\mathrm{el}}$ & 64,49 & $\mathrm{MW}$ \\
\hline CHP heat capacity & $\dot{Q}_{S}$ & 121,25 & $\mathrm{MW}$ \\
\hline Heat for preparation utility water & $Q_{\dot{U} W}$ & 18,18 & $\mathrm{MW}$ \\
\hline $\begin{array}{c}\text { Maximum heat influx into the } \\
\text { adsorption chiller }\end{array}$ & $\dot{Q_{z}}$ & 103,07 & $\mathrm{MW}$ \\
\hline $\begin{array}{c}\text { Maximum cooling capacity } \\
\text { Performance) Bry Air chiller } \\
\text { ADC }\end{array}$ & $\dot{Q}_{C h}$ & 37,1 & $\mathrm{MW}$ \\
\hline $\begin{array}{c}\text { EUF } \\
\mathrm{COP}\end{array}$ & 0,36 & - \\
\hline $\begin{array}{c}\text { (indicator of chemical energy } \\
\text { use of fuel in the trigeneration } \\
\text { system) }\end{array}$ & $\mathrm{EUF}_{\mathrm{T}}$ & 99,8 & {$[\%]$} \\
\hline $\begin{array}{c}\text { District water temperature drop } \\
\text { in the chiller }\end{array}$ & $\Delta \mathrm{T}_{\mathrm{z}}$ & 6.6 & ${ }^{\circ} \mathrm{C}$ \\
\hline $\begin{array}{c}\text { District water mass flow for heat } \\
\text { utility water }\end{array}$ & $\dot{m}$ & 149,85 & $\mathrm{~kg} / \mathrm{s}$ \\
\hline $\begin{array}{c}\text { District water mass flow for } \\
\text { adsorption chillers }\end{array}$ & $\dot{m}$ & 849,15 & $\mathrm{~kg} / \mathrm{s}$ \\
\hline
\end{tabular}

\section{Summary}

The main objective of this paper was to examine the effect of the application of adsorption chillers on the improved energy efficiency of a conventional power plant. Actions aimed at increasing and improving it, as well as the savings in non-renewable energy resources, are becoming an increasingly important aspect of the operation of power plants. An indicator that clearly demonstrates the relative energy effect of the application of trigeneration technology, i.e. the utilisation of the heat capacity of the cogeneration unit for additional production of coolant. During summer CHP power plants is operating only for production heat for preparation utility water but it is only 10 to $15 \%$ of the total heat output. The consequence of this situation is the limitation of electricity production because in CHP systems, the production of electricity is dependent on heat production. Using adsorption chillers, the CHP system operates at the same load as in winter and additionally produce chilled water for air conditioning. In this case maximum cooling capacity is about $37,1 \mathrm{MW}$. This type of solution can be implemented if we find, cold consumers for example, large refrigeration centers in office buildings, data storage centers (server rooms) and shopping centers, whose demand for cold is amounts to several MW.

\section{Acknowledgements}

The first author acknowledges the support provided by Faculty of Energy and Fuels, AGH University of Science and Technology, Cracow, Poland. The article was funded from government money Faculty of Energy and Fuels number 11.11.210.216

\section{References}

1. Directive 2012/27/EU of the European Parliament and of the Council of 25 October 2012 on energy efficiency, amending Directives 2009/125/EC and 2010/30/EU and repealing Directives 2004/8/EC and 2006/32/EC OJ L 315

2. OECD, Environmental Outlook to 2050 (2012)

3. P. Byrne et al., Renewable and Sustainable Energy Rev. 47703 (2015)

4. L. Zisheng, W. Ruzhu, Applied Energy 174224 (2016)

5. K. Sztekler, M. Komorowski, M. Tarnowska, Ł. Posak, E3S Web of Conferences 10, 00095 (2016)

6. K. Sztekler, K. Wojciechowski, M. Komorowski, M. Tarnowska, E3S Web of Conferences 14, 01031 (2017)

7. R. Z. Wang, Y. X. Xu, J. Y. Wu, M. Li, H. B. Shou, Appl. Therm. Eng. 22603 (2002)

8. R. Z. Wang, M. Li, Y. X. Xu, J. Y. Wu, Solar Energy 68189 (2000)

9. X. J. Zhang, R. Z. Wang, Renewable Energy 27401 (2002)

10. G. Najeh, G. Slimane, M. Souad, B. Riad, E.G. Mohammed, Case Studies in Thermal Engineering 8337 (2016) 
11. Bry-Air technical data, https://www.bryair.com /products-solutions/adsorption-chillers

12. Internal technological documentation from power plants Kozienice, Poland

13. Thu K, Yanagi H, Saha B B and Ng K C 2013 Int J. of Heat and Mass Transfer 65662 